\title{
STRATEGIC DIAGNOSIS OF INSTITUTIONS SUPPLIERS AND DEMANDERS OF TECHNOLOGY IN FISHERIES AND AQUACULTURE
}

\author{
REBELATTO JR., I.A.; FLORES, R.M.V.*; LIMA, A.F.; SILVA, A.P.; \\ ROSA, D.K.; PINHO, M.S. \& SOARES, S.S. \\ Embrapa Pesca e Aquicultura \\ *Corresponding author: roberto.valladao@embrapa.br
}

\begin{abstract}
Rebelatto Jr., I.A.; Flores, R.M.V.; Lima, A.F.; Silva, A.P.; Rosa, D.K.; Pinho, M.S. \& Soares, S.S. 2014. Strategic diagnosis of institutions suppliers and demanders of technology in fisheries and aquaculture. Braz. J. Aquat. Sci. Technol. 18(2): NB5-8. elSSN 1983-9057. DOI: 10.14210/bjast.v18n2.pNB5-8 The research project named Aquapesquisa aimed to do a survey and a database of public and private organizations, suppliers and demanders of technologies and knowledge of the Brazilian national fishing and aquaculture sector and, afterwards, with the application of a quantitative survey to the registered organizations, characterize and describe the profile of the companies in this sector. The first stage of this survey was conducted between February and December of 2012, which was the search for institutions that fit the categories: research and development; rural extension and technical assistance; science and technology; fishing colonies and associations. In this first stage 3,480 institutions were identified throughout Brazil. On a second stage, which was held between December of 2012 and July of 2013, the identified institutions were asked to answer voluntarily to some questionnaires, with 273 institutions responding to the survey. For this survey, four questionnaires were developed by the technical staff of Embrapa Fisheries and Aquaculture; the main questionnaire applied to all institutions, while the other 3 specific questionnaires were applied according with the area of work developed by each institution. The questionnaires were applied in electronic media via web or through phone calls. The results obtained from this survey is a diagnosis of the sector, presenting, among other information: the profile of the institutions that responded to the survey; the main aquatic species used in the work undertaken in each region; the main methods used for technology transfer; the main sponsors of research projects; the main public who have used the developed technologies; a list of the courses in fishing and aquaculture offered by the educational institutions and; the main demands of the technical assistance professionals for technologies and knowledge in fishing and aquaculture. It also presents a register of researchers and their respective areas of research.
\end{abstract}

Key words: Aquaculture; Fishing; Strategic Diagnosis;Technology.

Fish consumption accounts for approximately $17 \%$ of the world per capita consumption of animal protein (FAO, 2013). The world population and the purchasing power in emerging countries are expected to increase for the next decades and the global demand for food might be one of the consequences. In order to expand food production, the use of natural resources from Brazil will contribute significantly to the supply of seafood in the coming years (MPA, 2012).

Considering the potential of food production and the lack of robust statistical data for the sector of fisheries and aquaculture in Brazil (Flores and Pedroza Filho, 2013), Embrapa Fisheries and Aquaculture sponsored by the Ministry of Fisheries and Aquaculture (MPA) has coordinated a research project in order to obtain further information of the sector. In this study a diagnosis of the sector in the country was held, seeking to fill an information gap regarding to suppliers and demanders of technology institutions. On the first stage, conducted between February and December of 2012, an amount of 3,480 institutions were identified across Brazil. On the second stage, held between December of 2012 and July of 2013, when the institutions identified were asked to answer voluntarily to some questionnaires, it was obtained responses from the 273 institutions.
As a product of this project, a document presenting the profile of the institutions that answered to the questionnaire was built, as well as a list of their activities, their infrastructures, aquatic species that are used in their work, and their main demands. It was also asked for specific information in the questionnaire, directed to the research, technical assistance and educational institutions.

The organization of this work took place in four steps: built of a web interface for managing data; data collection for registration of institutions; application of the questionnaires and; compilation of the data collected and elaboration of a diagnosis. The survey was characterized by the search for institutions that fit the following categories: research and development; rural extension and technical assistance; science and technology; fishing colonies and associations. The registration was done initially with searches for information on the Internet, dividing the search for Brazilians regions. The following procedure was the telephone contact to the institutions found, as needed. Along with the collection it was performed a scan of the database, the search of the geographic coordinates of each institution and the confirmation of the data with each of them. A web interface was developed to allow the research administrator to update and consult 
all fields surveyed. Besides, the system allowed the administrator to insert and delete records, to export the data to Excel, making reports as needed. Also, the administrator can insert and delete users, creating logins and passwords for them, which may have different levels of access defined by the administrator.

The questionnaires used in the study were prepared by the technical staff of Embrapa Fisheries and Aquaculture. A main questionnaire that seeks to characterize the institutions, their infrastructures and activities and 3 questionnaires destined only to institutions that have any of the following activities: research; technical assistance and rural extension; and education. The questionnaires are available in a Web site, created exclusively for this study. Institutions registered in the previous step received an email containing their individual login and password.

In addition, telephone calls were made to 1,402 of the registered institutions that did not have an email address, with 92 of these institutions participating in the study by answering the questionnaires by phone. In all (web site plus telephone contacts), 273 institutions answered the research questionnaires $(7.84 \%$ of the total identified and registered). Finally, the collected data were compiled and the diagnosis was based on the information acquired.

Regarding to the geographical location, there was a predominance of the Brazilian Northeast institutions (Table 1). Among the 3,480 institutions found, $45.55 \%$ are from the Northeast, $18.87 \%$ are from the Southeast, $17.29 \%$ are from the North, $12.26 \%$ are from the South and $6.03 \%$ are from the Midwest. If we consider only those institutions that responded to the research questionnaires, we have the following geographic distribution: $41.39 \%$ are in the Northeast, $21.98 \%$ are from the North, $15.75 \%$ are from the Southeast, $11.72 \%$ are from the South and $9.16 \%$ are from the Midwest.

The public participating in this survey is very diversified, ranging from fishing colonies to large research institutions. Most of the institutions that answered to the research questionnaires $(52.75 \%)$ reported that among the activities developed by the institution, there are activities related to associations. The research activities were among the activities developed by $21.61 \%$ of the institutions that answered the questionnaires, these being the most mentioned activities.

Regarding to how long these institutions have been developing activities in fisheries or aquaculture, is noted that the activities related to aquaculture started in a more recent period. While $33.33 \%$ of the institutions that develop activities related to fisheries reported to perform these activities for more than 20 years and only $24.20 \%$ of these institutions reported to perform these activities for less than 5 years. The situation is reversed when analyzed how long these institutions develop activities in aquaculture, with only $17.60 \%$ of the institutions reporting develop activities in aquaculture for over 20 years, while $33.60 \%$ of them develop these activities for less than 5 years.

Regarding to the hydro-geographic scope of the work performed by the institutions, $64.08 \%$ reported to develop their activities in the inland waters, $39.59 \%$ reported develop activities in marine waters, while $26.53 \%$ reported develop activities in estuarine waters, with $22.04 \%$ of the institutions reporting to develop activities in more than one of the mentioned hydro-geographic areas simultaneously.

In relation to the aquatic species that have been part of the work or study of these institutions, the most mentioned species vary according to the state and region. The tilapia (Oreochromis niloticus) is among the fish species most frequently mentioned in most states, except the states of the North Region, where its production is not allowed. The tilapia was the most mentioned species in the Northeast and Southeast regions. The tambaqui (Colossoma macropomum), found in the Amazon and Orinoco basins in its wild form, was the most mentioned species in the North Region. The surubim (Pseudoplatystoma spp.), a genus of several South American catfish species, is the most mentioned species in the Midwest. While in the South Region the most mentioned species is the tainha (Mugil spp.).

Table 1 - Number of institutions working with fisheries and aquaculture and number of institutions that responded to the survey by Brazilian Regions.

\begin{tabular}{lcccc}
\hline \hline Brazilian & $\begin{array}{c}\text { Number of } \\
\text { Regions } \\
\text { institutions working } \\
\text { with Fisheries and } \\
\text { Aquaculture }\end{array}$ & $\%$ FO & $\begin{array}{c}\text { Number of } \\
\text { institutions that } \\
\text { responded to the } \\
\text { survey }\end{array}$ & $\%$ FO \\
\hline Northeast & 1,585 & $45.55 \%$ & 113 & $41.39 \%$ \\
North & 602 & $17.30 \%$ & 60 & $21.98 \%$ \\
Southeast & 656 & $18.85 \%$ & 43 & $15.75 \%$ \\
South & 427 & $12.27 \%$ & 32 & $11.72 \%$ \\
Midwest & 210 & $6.03 \%$ & 25 & $9.16 \%$ \\
\hline TOTAL & $\mathbf{3 , 4 8 0}$ & $\mathbf{1 0 0 \%}$ & $\mathbf{2 7 3}$ & $\mathbf{1 0 0 \%}$ \\
\hline \hline
\end{tabular}




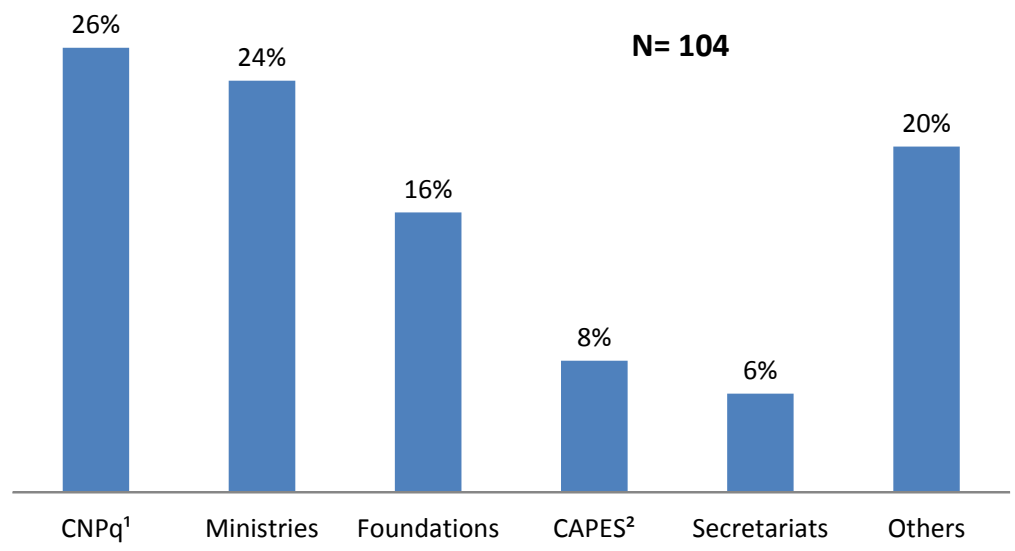

Figure 1 - Main sponsors of the projects developed by the institutions surveyed. ${ }^{1} \mathrm{CNPq}$ (National Counsel of Technological and Scientific Development); ${ }^{2}$ CAPES (Coordination for the Improvement of Higher Education Personnel)

When we exclude the fish species and analyze the others aquatic species, the shrimp species are the most frequently mentioned, with $46.61 \%$ of the total quotations. Most of the institutions that mentioned work with shrimps are located in the Northeast Region. Oysters $(11.02 \%)$ and crabs $(8.47 \%)$ come next in the order of the species most mentioned in the survey.

Regarding to the infrastructure present in these institutions, $39.19 \%$ reported owning boats, $41.39 \%$ have fishing equipments, $6.23 \%$ have fishing workshops or boatyards (mini-boatyards) and $18,01 \%$ have unities of technology demonstration or technology reference. The structures most commonly used during the fattening of fish are the fish cages, present in $18.63 \%$ of the institutions surveyed, and dug ponds, present in $17.22 \%$ of these institutions. The larviculture laboratories are present in the infrastructure of $17.22 \%$ of the institutions, while limnology laboratories are present in $11.36 \%$ of these institutions and pathology laboratories are present in $5.86 \%$ of them. For the transport of aquatic organisms, $16.48 \%$ of the institutions have trucks, $10.26 \%$ have oxygen tanks, $9.2 \%$ have coldstorage structures and $8.79 \%$ have structures to the transport of live aquatic organisms. In relation to the slaughter and processing, $15.75 \%$ of the institutions have ice machines, $9.89 \%$ have refrigerators and 6.96 $\%$ have equipment of air conditioner.

The institutions with research activities have registered 110 research professionals, with 61 of these professionals being employees of Embrapa. The pisciculture area is the one with the largest number of professionals registered, with $66.36 \%$ of these registered professionals stating that as one of their areas of expertise. Eighteen institutions informed the technologies that they have developed in the last 10 years related to fisheries and aquaculture, listing a total of 65 technologies developed. These institutions with research activities also informed the sources of funding for their research (research sponsors, Figure 1). The CNPq (National Counsel of Technological and Scientific Development) and the ministries are the most used sources of funding, with respectively $25.96 \%$ and $24.04 \%$ of institutions with research activities using these sources. Among the public that most have used the technologies and knowledge that have been developed are: academic audience (25\%), rural extension $(22.58 \%)$ and associations (19.35\%).

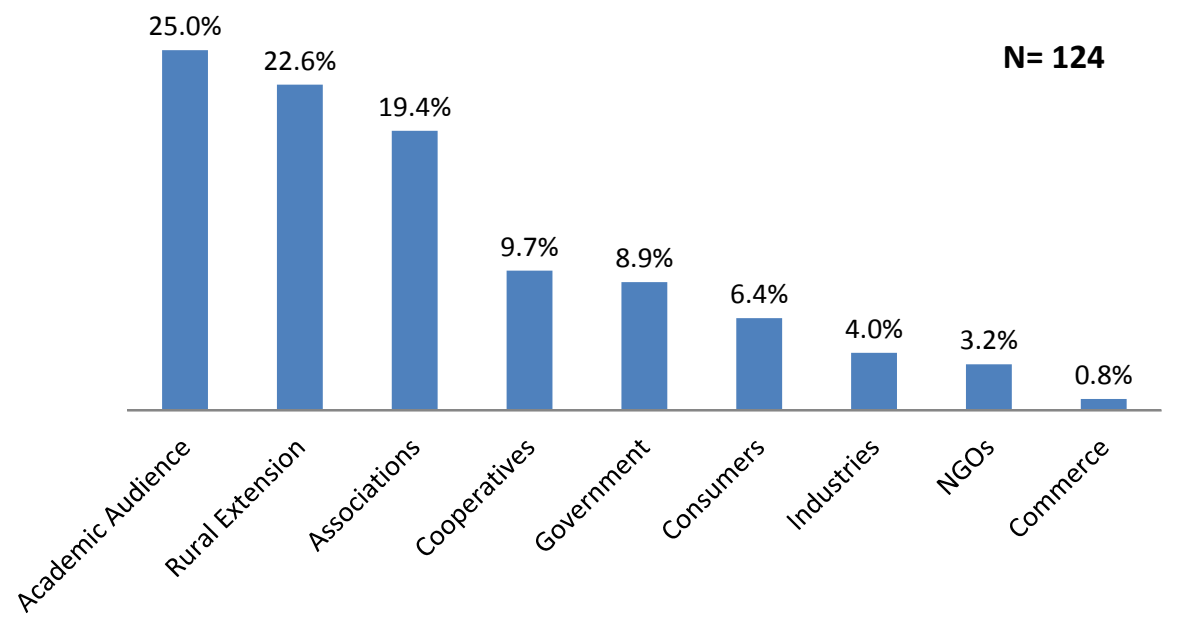

Figure 2 - Main public that have used the technologies and knowledge developed by the surveyed institutions. 
There were few respondents of the survey who reported acting in the field of education. Among these institutions, 26 reported to have classroom courses in the fishing area, offered by 12 institutions, and 26 classroom courses in the area of aquaculture, offered by 19 institutions. On the other hand, distance education courses are offered in a smaller number, having been pointed by only two institutions, each one offering one course. These courses are offered from the technical level to the doctoral level.

The questionnaire destined to the institutions that work with technical assistance and rural extension was answered by 27 institutions, although some of these institutions do not work exclusively with fisheries and aquaculture. These institutions together have reported a total of 2,320 rural extension professionals, but only 78 of these professionals provides assistance to fishermen and 119 of them provides assistance to fish farmers. The institutions informed about the educational degree of 372 of these professionals, $37.10 \%$ of them are undergraduate, $6.72 \%$ have done specialization courses at the post-graduate Lato Sensu level, $21.77 \%$ have master's degrees, $19.89 \%$ have doctor's degree and $1.88 \%$ has postdoctoral degree, while $12.63 \%$ are only in the technical level. Most institutions (70\%) reported to promote constant technological updating to the technical assistance professionals, and $68.97 \%$ of the institutions have already trained their professionals to work with fishermen and / or fish farmers. The main rural extension methodology used is individual visits to the producers (25\%), followed by field days for farmers $(20.24 \%)$, continuous training in production techniques $(16.67 \%)$ and technical tours (14.29\%).

There is a global trend of increase of demand for products from fisheries and aquaculture and Brazil has the conditions to become one of the world powers of this sector. Brazil has the largest amount of fresh water on the planet and one of the largest coastal extensions in its territory, suitable climate for fish production and large scale production of the main raw materials used in the manufacture of animal feed.

Through all data obtained in this survey was possible to identified the actual scenario of this sector in Brazil, the infrastructure of the institutions surveyed and the activities that they develop, what has been done in terms of research, the courses that are offered by the educational institutions and what has been done by the institutions of technical assistance and rural extension.

This was the first survey realized with this purpose, and it must be repeated continually seeking to improve the methodology used and increase the number of institutions surveyed. Thus we can follow the evolution of this sector in Brazil.

\section{ACKNOWLEDMENTS}

The authors thank the Ministry of Fisheries and Aquaculture (MPA) for sponsoring this project.

\section{REFERENCES}

Castro, A.M.G. de; Cobbe, R.V. \& Goedert, W.J. 1995. Prospecção de demandas tecnológicas: manual tecnológico para o SNPA. Brasília, DF. EMBRAPA-DPD.

FAO. 2013 FAO Statistical Yearbook 2013 - World Food and Agriculture. Roma, Food and Agriculture Organization of the United Nations.

Flores, R.M.V. \& Pedroza Filho, M.X. 2013. Como multiplicar os peixes? Perspectivas da aquicultura brasileira. Ciên. Cult. 65(2): 04-05.

Lima, A.; Prysthon, A.; Rosa, D.K.; Luiz, D. de B.; Sousa, D.; Routledge, E.A.B.; Mataveli, M.; Ummus, M.; Cruvinel, P.; Barroso, R.; Mattos, S. M. G. de \& Soares, S. 2012. Relatório técnico do seminário nacional de prospecção de demandas da cadeia produtiva da pesca: PROSPESQUE. Brasília, DF. Embrapa.

Ministério da Pesca e Aquicultura - MPA. 2012. Boletim estatístico da pesca e aquicultura - Brasil 2010. Brasília, DF. Ministério da Pesca e Aquicultura.
Submetido: Dezembro/2013 Revisado: Março/2014 Aceito: Março/2014 